\title{
Phytochemicals and antioxidant activity in the kenaf plant (Hibiscus cannabinus L.)
}

\author{
Jaihyunk Ryu $\cdot$ Soon-Jae Kwon $\cdot$ Joon-Woo Ahn $\cdot$ Yeong Deuk Jo $\cdot$ Sang Hoon Kim $\cdot$ Sang Wook Jeong \\ Min Kyu Lee $\cdot$ Jin-Baek Kim $\cdot$ Si-Yong Kang
}

Received: 29 May 2017 / Revised: 20 June 2017 / Accepted: 20 June 2017

(c) Korean Society for Plant Biotechnology

\begin{abstract}
Chemical compounds from four different tissues of the kenaf plant (Hibiscus cannabinus), a valuable medicinal crop originating from Africa, were examined to determine its potential for use as a new drug material. Leaves, bark, flowers, and seeds were harvested to identify phytochemical compounds and measure antioxidant activities. Gas chromatography mass spectrometry analyses identified 22 different phytocompounds in hexane extracts of the different parts of the kenaf plant. The most abundant volatile compounds were E-phytol (32.4\%), linolenic acid (47.3\%), trisiloxane-1,1,1,5,5,5-hexamethyl3,3-bis[(trimethylsilyl)oxy] (16.4\%), and linoleic acid (46.4\%) in leaves, bark, flowers, and seeds, respectively. Ultra-high performance liquid chromatography identified the major compounds in the different parts of the kenaf plant as kaemperitrin, caffeic acid, myricetin glycoside, and $p$-hydroxybenzoic acid in leaves, bark, flowers, and seeds, respectively. Water extracts of flowers, leaves, and seeds exhibited the greatest DPPH radical scavenging activity and SOD activity. Our analyses suggest that water is the optimal solvent, as it extracted the greatest quantity of functional compounds with the highest levels of antioxidant activity. These results provide valuable information for the development of environmentally friendly natural products for the pharmaceutical industry.
\end{abstract}

Keywords Kenaf, Functional compounds, Antioxidant activities, Drug materials

J. Ryu - S.-J. Kwon - J.-W. Ahn • Y. D. Jo - S. H. Kim • M. K. Lee $\cdot$ J.-B. Kim $\cdot$ S.-Y. Kang $(\varangle)$

Advanced Radiation Technology Institute, Korea Atomic Energy Research Institute, Jeongup, Jeonbuk 56212, Korea

e-mail: sykang@kaeri.re.kr

S. W. Jeong

Jangheung Research Institute for Mushroom Industry, Jangheung 59338, Korea

\section{Introduction}

Phytochemicals are biologically active plant chemicals that provide various health benefits (Khare, 2007; Jin et al. 2013). They are naturally occurring bioactive substances that provide plants with particular defense mechanisms and protect them from various diseases. An important category of phytochemicals commonly present in plants has high antioxidant activity (Yusri et al. 2012; Chen et al. 2014). Phytochemical analyses are of paramount importance for the identification of new sources of therapeutically and industrially valuable compounds with medicinal significance and for the best and most judicious use of naturally available materials (Hossain et al. 2011).

Flavonoid and phenolic compounds, which exhibit a broad range of biological activities, are known to be more abundant than flavonoid monomers in plants (Wang et al. 2008; Jin et al. 2013). The wide use of plants as food, food additives and drug has increased the number of researches investigating the phytochemicals and biological activity of these sources (Rauter et al. 2002; Nyam et al. 2009). The medicinal plants were used for health care because they contain aromatic components of high therapeutic potential. Especially, essential oils and fatty acids are widely used in medicine, as flavoring additives in the food industry, and as fragrances in the cosmetic industry (Kobaisy et al. 2001; Ryu et al. 2013). Kenaf, an annual herbaceous crop of the Malvaceae family, is a short-day plant. Kenaf, a valuable medicinal crop originated from Africa, is contained various functional compounds. The kenaf leaf was applied to Guinea worms and the stem bark has been used for anaemia in Africa (Alexopoulou et al. 2013). In ayurvedic medicine, the kenaf leaves are used for bilious, blood, diabetes, coughs and throat disorders (Khare, 2007; Alexopoulou et al. 2013; Jin et al. 2013). The flower juice is used for biliousness (Alexopoulou et al. 2013). The seeds are also consumed 
to weight increase and bruises (Kubmarawa et al. 2009; Alexopoulou et al. 2013). The kenaf leaf and seed contains a variety of different compounds, including phenolic compounds, flavonoids, essential oils, and fatty acids (Mohamed et al. 1995; Jin et al. 2013; Ryu et al. 2013; Nandagopalan et al. 2015; Obouayeba et al. 2015). Kenaf has been reported to exhibit properties associated with anodynes, aperitifs, aphrodisiacs, anti-inflammatory medications, and antioxidants for leaf and seed. It has also been related to weight gain, anemia, and fatigue (Kobaisy et al. 2001; Khare, 2007; Kubmarawa et al. 2009; Alexopoulou et al. 2013). Phenylpropanoids, which are abundant in the kenaf leaf, are important for these beneficial health effects (Jin et al. 2013; Ryu et al. 2016). Various biologically active compounds have been reported in the kenaf seed, including omega-3 fatty acids, phenolic compounds, and sterols (Alexopoulou et al. 2013; Ryu et al. 2013). However, studies on the phytochemical of different parts were little known.

A selection of the best solvents for the extraction of chemical compounds from plant materials is important to improving the efficiency of extraction yield (Sultana et al. 2007). Therefore, it is essential to determine the solvents on the extraction of functional compounds and antioxidant properties of kenaf to select an optimal solvent for the extraction of the bioactive compounds from the different parts of the kenaf plant.

This study analyzed the nutritional properties, functional compounds, and antioxidant activities in the leaves, stem bark, flowers, and seeds of kenaf. This is the first report on the phytochemical composition of the different parts of the kenaf plant. Additionally, the differences in antioxidant activity and major components that were a result of the different solvents were investigated to identify novel, potentially environmentally friendly natural products that would be useful in the food industry.

\section{Materials and Methods}

Plant materials and extraction

The 'Auxu' cultivars were studied. The leaves, bark, flowers, and seed of the kenaf plant were harvested (Fig. 1) and freeze drying. Ten gram of each samples were extracted for 24 hour with $50 \mathrm{ml}$ of methanol, water, ethanol and chloroform. Extract samples used for determine total polyphenol content, flavonoid content, perform ultra-high performance liquid chromatography (UPLC) and antioxidant analysis.

Gas chromatography mass spectrometry (GC-MS) analysis

Plant extraction for GC-MS analysis was determined by previously study (Ryu et al. 2013), with the following modifications. The powdered material of the leaf, stem bark, flower, and seed $(10 \mathrm{~g})$ was extracted in $50 \mathrm{~mL}$ hexane for $2 \mathrm{~h}$, and $500 \mu \mathrm{L} 2 \mathrm{~N}$ potassium hydroxide in methanol was added. From this, $2 \mu \mathrm{L}$ of the extracts from the different parts of the kenaf plant was analyzed by GC-MS (Plus-2010, Shimadzu, Kyoto, Japan). The chemical composition of the different parts of the kenaf plant were analyzed using a GC-MS instrument equipped with an HP-88 capillary column $(60 \mathrm{~m} \times 0.25 \mathrm{~mm} \times 0.25 \mathrm{~m}, \mathrm{~J} \& \mathrm{~W}$ Scientific, C.L. USA $)$ under the following conditions: ionization voltage, $70 \mathrm{eV}$; mass scan range, 50-450 mass units; injector temperature, $230^{\circ} \mathrm{C}$; detector temperature, $230^{\circ} \mathrm{C}$; inject volume, $1 \mu \mathrm{L}$; split ratio, 1:30; carrier gas, helium; and flow rate, 1.7 $\mathrm{mL} / \mathrm{min}$. The column temperature program specified an isothermal temperature of $40^{\circ} \mathrm{C}$ for $5 \mathrm{~min}$ followed by an increase to $180^{\circ} \mathrm{C}$ at a rate of $5^{\circ} \mathrm{C} / \mathrm{min}$ and a subsequent increase to $28^{\circ} \mathrm{C}$ at a rate of $1^{\circ} \mathrm{C} / \mathrm{min}$. We identified the substances present in the extracts by retention time (RT) and mass spectra database (Nist. 62 Library).
A

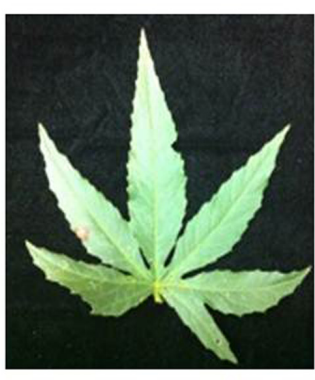

B

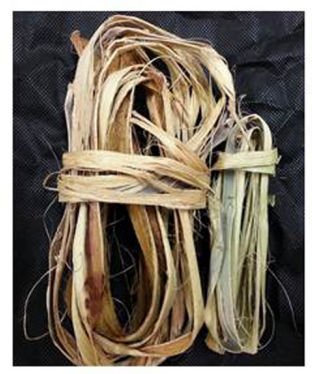

C

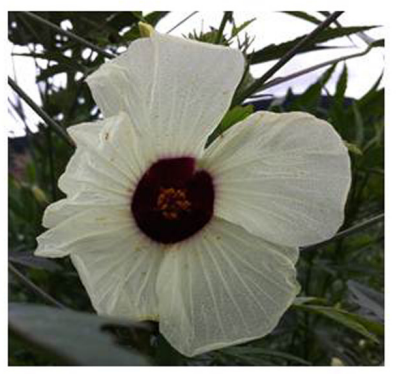

D

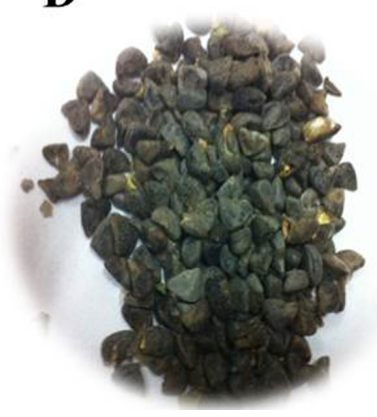

Fig. 1 Profiles of the different parts of the kenaf plant. A: leaf; B: stem bark; C: flower; D: seeds 
Total phenolic content

The total phenolic content (TPC) was determined with the Folin-Ciocalteau colorimetric method (Jin et al. 2013). A small quantity $(0.2 \mathrm{~mL})$ of each extract and $1.5 \mathrm{~mL}$ of FolinCiocalteau reagent $(20 \% \mathrm{v} / \mathrm{v})$ were mixed thoroughly. After $4 \mathrm{~mL} \mathrm{Na}_{2} \mathrm{CO}_{3}$ (7\%) was added, and fill up to $10 \mathrm{~mL}$ with water. The mixture was allowed to dark exposure with room temperature at $90 \mathrm{~min}$. The absorbance was measured at $760 \mathrm{~nm}$ using a UV-spectrophotometer (UV-1800, Shimazuda, Kyoto, Japan). TPC was calculated using a calibration curve of tannic acid.

Total flavonoid content

The total flavonoid content (TFC) content in different part of kenaf was determined by Zhishen et al., 1999. Each extract samples $(0.2 \mathrm{ml})$ was added to $4 \mathrm{~mL}$ double-distilled water and $0.3 \mathrm{~mL}$ of $5 \% \mathrm{NaNO}_{2}$ to the flask. The samples were maintained for $5 \mathrm{~min}$, and $0.3 \mathrm{~mL}$ of $10 \% \mathrm{AlCl}_{3}$ was added. After $6 \mathrm{~min}, 2 \mathrm{~mL} \mathrm{NaOH}$ and fill double-distilled water up to $10 \mathrm{~mL}$. The absorbance was measured at $510 \mathrm{~nm}$. TFC was calculated using a calibration curve of quercetin equivalents.

Ultra-high performance liquid chromatography (UPLC) analysis

Functional compounds were analyzed with a UPLC system (CBM-20A, Shimadzu Co., Kyoto, Japan) with two gradient pump systems (LC-30AD, Shimadzu, Kyoto, Japan), a UV detector (SPD-M30A, Shimadzu), an auto sample injector (SIL-30AC, Shimadzu), and a column oven (CTO-30A, Shimadzu). Separation was achieved on an XR-ODS column $(3.0 \times 100 \mathrm{~mm}, 1.8 \mu \mathrm{m}$, Shimadzu, Japan) using a linear gradient elution program with a mobile phase containing solvent A $[0.1 \%$ trifluoroacetic acid $(\mathrm{v} / \mathrm{v})$ in distilled deionized water $]$ and solvent B $[0.1 \%$ trifluoroacetic acid $(\mathrm{v} / \mathrm{v})$ in acetonitrile]. For UPLC analysis, ground samples (5 g) were extracted in $5 \mathrm{~mL}$ of each solvent (methanol, ethanol, water, and chloroform) for $60 \mathrm{~min}$ and filtered through a $0.45-\mu \mathrm{m}$ membrane filter. Flavonoids and phenolic acids were separated using the following gradient: $0-5 \mathrm{~min}, 10-15 \% \mathrm{~B}$; 5-10 min, 15-20\% B; 10-15 min, 20-30\% B; 15-20 min, 30-50\% B; 20-25 min, 50-75\% B; 25-30 min, 75-100\% B; $30-32 \mathrm{~min}, 100-5 \% \mathrm{~B}$; and $32-35 \mathrm{~min}, 5-0 \%$ B. Flavonoids, phenolic acids, and anthocyanins were detected at 280, 350, and $520 \mathrm{~nm}$, respectively.
Determination of antioxidant activity

The 2,2-diphenyl-1-picrylhydrazyl (DPPH) radical scavenging activity DPPH radical scavenging activity was measured by Jin et al. 2013. Each solvent (methanol, ethanol, water, and chloroform) extract added to $0.15 \mathrm{mM} \mathrm{DPPH}$, and after $30 \mathrm{~min}$, the remaining DPPH radicals were quantified using a plate reader (Benchmark Plus; Bio-Rad, Hercules, CA, USA) at $517 \mathrm{~nm}$. The super oxide dismutase (SOD) activity was measured by SOD assay kit (Dojindo Molecular Technologies, USA) manual. The DPPH and SOD activity effect was calculated as follows:

$$
[(1-A s / A c) \times 100 \%]
$$

$A s$ : absorbance value with sample; $A c$ : absorbance value without extract solution.

Statistical analysis

The chemical analysis data were subjected to analysis of variance using a multiple comparisons method with the statistical software package SPSS, Version 12 (SPSS Institute, USA). Differences were determined to be significant at $p<$ 0.05 . When the treatment effect was significant, the means were separated using Duncan's multiple range tests.

\section{Results}

GC-MS analysis

The compounds identified in the different parts of the kenaf plant, along with their RT, molecular formula, molecular weight and percentage, are shown in Table 1 and Fig. S1. The leaf extract showed 13 phytocompounds, including 3,7,11,15-Tetramethyl-2-hexadecen (4.4\%), Tetradecanoic acid (0.8\%), 6,10,14-trimethyl-pentadecan-2-ol (0.9\%), 6,10,14Trimethyl-2-pentadecanone (3.4\%), Hexadecanoic acid (14.3\%), 9-Octadecenoic acid (2.9\%), Phytol acetate (2.3\%), 9,12Octadecadienoic acid (6.8\%), Phytol (32.4\%), 9,12,15-Octadecatrienoic acid $(n=6,0.7 \%), 9,12,15$-Octadecatrienoic acid $(n=3,27.6 \%), 2-5$-oxohexyl-cyclopentanone $(1.4 \%)$, and 2,6,10,14,18,22-Tetracosahexaene (2.1\%). Eight different phytocomponents were identified in the stem bark extract of kenaf: Hexadecanoic acid (25.4\%), 9-Hexadecenoic acid (3.0\%), Octadecanoic acid (3.1\%), 9-Octadecenoic acid (1.2), Phytol acetate (0.7\%), 9,12-Octadecadienoic acid (10.7\%), Phytol (8.7\%), and 9,12,15-Octadecatrienoic acid 
Table 1 Volatile constituents in four different kenaf tissue types

\begin{tabular}{|c|c|c|c|c|c|}
\hline No. & $\mathrm{RT}(\min ) *$ & Name of the compound & $\begin{array}{c}\text { Molecular } \\
\text { formula }\end{array}$ & MW & $\begin{array}{c}\text { Total } \\
\%\end{array}$ \\
\hline \multicolumn{6}{|c|}{ Leaf } \\
\hline 1 & 12.6 & $3,7,11,15$ tetramethyl-2 hexadecen-1-ol (Z-phytol) & $\mathrm{C}_{20} \mathrm{H}_{40} \mathrm{O}$ & 296 & 4.4 \\
\hline 2 & 13.9 & Tetradecanoic acid & $\mathrm{C}_{15} \mathrm{H}_{30} \mathrm{O}_{2}$ & 242 & 0.8 \\
\hline 3 & 15.1 & 6,10,14-Trimethyl-pentadecan-2-ol & $\mathrm{C}_{18} \mathrm{H}_{38} \mathrm{O}$ & 270 & 0.9 \\
\hline 4 & 15.3 & 2-Pentadecanone, 6,10,14-trimethyl & $\mathrm{C}_{18} \mathrm{H}_{36} \mathrm{O}$ & 268 & 3.4 \\
\hline 5 & 15.5 & Hexadecanoic acid & $\mathrm{C}_{17} \mathrm{H}_{34} \mathrm{O}_{2}$ & 270 & 14.3 \\
\hline 6 & 18.2 & 9-Octadecenoic acid & $\mathrm{C}_{17} \mathrm{H}_{32} \mathrm{O}_{2}$ & 268 & 2.9 \\
\hline 7 & 18.8 & Phytol, acetate & $\mathrm{C}_{22} \mathrm{H}_{42} \mathrm{O}_{2}$ & 338 & 2.3 \\
\hline 8 & 19.4 & 9,12-Octadecadienoic acid & $\mathrm{C}_{19} \mathrm{H}_{34} \mathrm{O}_{2}$ & 296 & 6.8 \\
\hline 9 & 20.0 & E-Phytol & $\mathrm{C}_{20} \mathrm{H}_{40} \mathrm{O}$ & 296 & 32.4 \\
\hline 10 & 20.7 & $9,12,15$-Octadecatrienoic acid $(n=6)$ & $\mathrm{C}_{19} \mathrm{H}_{32} \mathrm{O}_{2}$ & 292 & 0.7 \\
\hline 11 & 21.0 & $9,12,15$-Octadecatrienoic acid $(n=3)$ & $\mathrm{C}_{19} \mathrm{H}_{32} \mathrm{O}_{2}$ & 292 & 27.6 \\
\hline 12 & 22.4 & Cyclopentanone, 2-(5-oxohexyl) & $\mathrm{C}_{11} \mathrm{H}_{18} \mathrm{O}_{2}$ & 182 & 1.4 \\
\hline 13 & 26.2 & 2,6,10,14,18,22-Tetracosahexaene & $\mathrm{C}_{30} \mathrm{H} 50$ & 410 & 2.1 \\
\hline \multicolumn{6}{|c|}{ 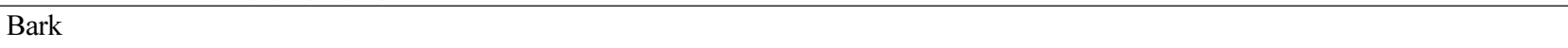 } \\
\hline 1 & 15.4 & Hexadecanoic acid & $\mathrm{C}_{17} \mathrm{H}_{34} \mathrm{O}_{2}$ & 270 & 25.4 \\
\hline 2 & 15.9 & 9-Hexadecenoic acid & $\mathrm{C}_{17} \mathrm{H}_{32} \mathrm{O}_{2}$ & 268 & 3.0 \\
\hline 3 & 17.5 & Octadecanoic acid & $\mathrm{C}_{19} \mathrm{H}_{38} \mathrm{O}_{2}$ & 298 & 3.1 \\
\hline 4 & 18.2 & 9-Octadecenoic acid & $\mathrm{C}_{19} \mathrm{H}_{38} \mathrm{O}_{2}$ & 296 & 1.2 \\
\hline 5 & 18.5 & Phytol, acetate & $\mathrm{C}_{22} \mathrm{H}_{42} \mathrm{O}_{2}$ & 338 & 0.7 \\
\hline 6 & 19.3 & 9,12-Octadecadienoic acid & $\mathrm{C}_{19} \mathrm{H}_{34} \mathrm{O}_{2}$ & 294 & 10.7 \\
\hline 7 & 20.3 & E-Phytol & $\mathrm{C}_{20} \mathrm{H}_{40} \mathrm{O}$ & 296 & 8.7 \\
\hline 8 & 20.9 & 9,12,15-Octadecatrienoic acid $(\mathrm{n}=3)$ & $\mathrm{C}_{19} \mathrm{H}_{32} \mathrm{O}_{2}$ & 292 & 47.3 \\
\hline \multicolumn{6}{|c|}{ Flower } \\
\hline 1 & 13.5 & Trisiloxane,1,1,1,5,5,5-hexamethyl-3,3-bis[(trimethylsilyl)oxy] & $\mathrm{C}_{12} \mathrm{H}_{36} \mathrm{O}_{2}$ & 384 & 16.4 \\
\hline 2 & 15.1 & 3-Isopropoxy-1,1,1,7,7,7-hexamethyl-3,5,5-tris(trimethylsiloxy)tetrasiloxane & $\mathrm{C}_{18} \mathrm{H}_{52} \mathrm{O}_{7}$ & 576 & 10.3 \\
\hline 3 & 15.3 & Hexadecanoic acid & $\mathrm{C}_{17} \mathrm{H}_{34} \mathrm{O}_{2}$ & 270 & 16.1 \\
\hline 4 & 16.8 & 15-methylhexadecanoic acid & $\mathrm{C}_{17} \mathrm{H}_{34} \mathrm{O}_{2}$ & 274 & 1.6 \\
\hline 5 & 17.3 & Octadecanoic acid & $\mathrm{C}_{19} \mathrm{H}_{38} \mathrm{O}_{2}$ & 298 & 5.3 \\
\hline 6 & 17.7 & Octasiloxane, $1,1,3,3,5,5,7,7,9,9,11,11,13,13,15,15$-hexadecamethyl & $\mathrm{C}_{16} \mathrm{H}_{50} \mathrm{O}_{7}$ & 578 & 8.6 \\
\hline 7 & 18.0 & 9-Octadecenoic acid & $\mathrm{C}_{19} \mathrm{H}_{36} \mathrm{O}_{2}$ & 296 & 12.5 \\
\hline 8 & 19.1 & 9,12-Octadecadienoic acid & $\mathrm{C}_{19} \mathrm{H}_{34} \mathrm{O}_{2}$ & 294 & 4.5 \\
\hline 9 & 20.7 & $9,12,15$-Octadecatrienoic acid $(n=3)$ & $\mathrm{C}_{19} \mathrm{H}_{32} \mathrm{O}_{2}$ & 292 & 7.2 \\
\hline 10 & 21.7 & Hexasiloxane, tetradecamethyl & $\mathrm{C}_{19} \mathrm{H}_{42} \mathrm{O}_{5}$ & 458 & 8.9 \\
\hline 11 & 27.6 & Heptasiloxane, hexadecamethyl & $\mathrm{C}_{16} \mathrm{H}_{48} \mathrm{O}_{6}$ & 532 & 8.6 \\
\hline \multicolumn{6}{|c|}{1} \\
\hline 1 & 13.9 & Tetradecanoic acid & $\mathrm{C}_{15} \mathrm{H}_{30} \mathrm{O}_{2}$ & 242 & 0.1 \\
\hline 2 & 15.4 & Hexadecanoic acid & $\mathrm{C}_{17} \mathrm{H}_{34} \mathrm{O}_{2}$ & 270 & 20.9 \\
\hline 3 & 16.0 & 9-Hexadecenoic acid & $\mathrm{C}_{17} \mathrm{H}_{32} \mathrm{O}_{2}$ & 268 & 0.6 \\
\hline 4 & 17.0 & cis-10-Heptadecenoic acid & $\mathrm{C}_{18} \mathrm{H}_{34} \mathrm{O}_{2}$ & 282 & 0.3 \\
\hline 5 & 17.5 & Octadecanoic acid & $\mathrm{C}_{19} \mathrm{H}_{38} \mathrm{O}_{2}$ & 298 & 2.2 \\
\hline 6 & 17.9 & 9-Octadecadienoic acid (trans) & $\mathrm{C}_{19} \mathrm{H}_{36} \mathrm{O}_{2}$ & 296 & 1.2 \\
\hline 7 & 18.2 & 9-Octadecenoic acid (cis) & $\mathrm{C}_{19} \mathrm{H}_{36} \mathrm{O}_{2}$ & 296 & 27.4 \\
\hline 8 & 19.4 & 9,12-Octadecadienoic acid & $\mathrm{C}_{19} \mathrm{H}_{34} \mathrm{O}_{2}$ & 294 & 46.4 \\
\hline 9 & 20.2 & Nonadecanoic acid & $\mathrm{C}_{21} \mathrm{H}_{42} \mathrm{O}_{2}$ & 326 & 0.3 \\
\hline 10 & 20.9 & $9,12,15$-Octadecatrienoic acid $(n=3)$ & $\mathrm{C}_{19} \mathrm{H}_{32} \mathrm{O}_{2}$ & 292 & 0.6 \\
\hline
\end{tabular}

*RT: Retention time

$(n=3,47.3 \%)$. Eleven phytocompounds were identified in the flower extract: Trisiloxane,1,1,1,5,5,5-hexamethyl-3,3bis[(trimethylsilyl)oxy] (16.4\%), 3-Isopropoxy-1,1,1,7,7,7- hexamethyl-3,5,5-tris(trimethylsiloxy)tetrasiloxane (10.3\%), Hexadecanoic acid (16.1\%), 15-Methylhexadecanoic acid (1.6\%), Octadecanoic acid (5.3\%), Octasiloxane, 1,1,3,3,5, 

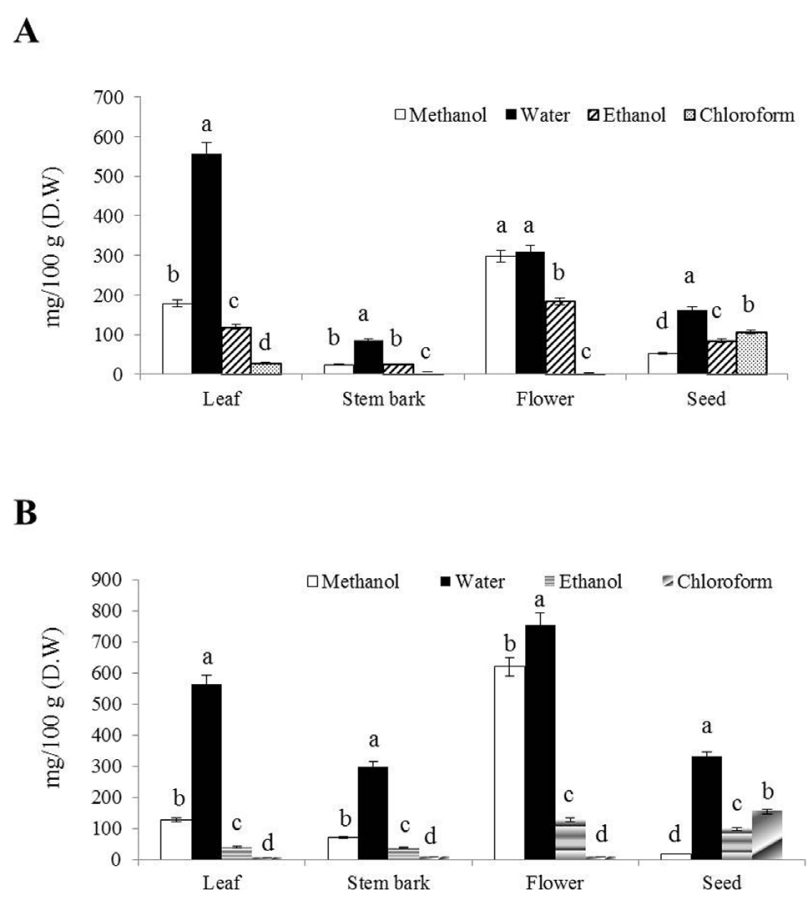

Fig. 2 Total phenolic and flavonoid content of different kenaf tissues. A: total phenolic content; B: total flavonoid content. Superscript letters indicate significant differences at the $5 \%$ level (Duncan's multiple range tests, $\mathrm{n}=3$ )

5,7,7,9,9,11,11,13,13,15,15-hexadecamethyl (8.6\%), 9-octadecenoic acid (12.5\%), 9,12-Octadecadienoic acid (4.5\%), 9,12,15-Octadecatrienoic acid ( $n=3,7.2 \%)$, Hexasiloxane tetradecamethyl (8.9\%), and Heptasiloxane hexadecamethyl (8.6\%). Ten different phytocomponents were identified in the seed extract: Tetradecanoic acid $(0.1 \%)$, Hexadecanoic acid (20.9\%), 9-Hexadecenoic acid (0.6\%), cis-10-Heptadecenoic acid $(0.3 \%)$, Octadecanoic acid (2.2\%), trans-9-Octadecadienoic acid (1.2\%), cis-9-Octadecadienoic acid (27.4\%), 9,12-Octadecadienoic acid (46.4\%), Nonadecanoic acid (0.3\%), and 9,12,15-Octadecatrienoic acid $(n=3,0.6 \%)$.

\section{TPC and TFC analysis}

TPC and TFC analysis of the extracts of the different parts of the kenaf plant are presented in Fig. 2. TPC obtained with the different solvents varied significantly, with the exception of the flower, in which the water and methanol extractions did not differ significantly. TPC and TFC increased in the extracts with increasing solvent polarity. Among all the extracts, water resulted in the highest TPC for all the different parts of the kenaf plant. The water extract of the leaf had the highest TPC $(555.9 \mathrm{mg} / 100 \mathrm{~g})$, followed by the water extract of the flower $(308.5 \mathrm{mg} / 100$ $\mathrm{g})$, the methanol extract of the flower $(298.6 \mathrm{mg} / 100 \mathrm{~g})$, the ethanol extract of the flower $(183.4 \mathrm{mg} / 100 \mathrm{~g})$, the methanol extract of the leaf $(178.1 \mathrm{mg} / 100 \mathrm{~g})$, the water extract of the seed $(162.7 \mathrm{mg} / 100 \mathrm{~g})$, the ethanol extract of the leaf $(119.1 \mathrm{mg} / 100 \mathrm{~g})$, the chloroform extract of the seed $(107.0 \mathrm{mg} / 100 \mathrm{~g})$, the water extract of the stem bark $(84.2 \mathrm{mg} / 100 \mathrm{~g})$, the ethanol extract of the seed $(83.7$ $\mathrm{mg} / 100 \mathrm{~g})$, the methanol extract of the seed $(52.6 \mathrm{mg} / 100$ $\mathrm{g})$, the chloroform extract of the leaf $(28.1 \mathrm{mg} / 100 \mathrm{~g})$, the ethanol extract of the stem bark $(24.8 \mathrm{mg} / 100 \mathrm{~g})$, the methanol extract of the stem bark $(23.2 \mathrm{mg} / 100 \mathrm{~g})$, the chloroform extract of the stem bark $(5.6 \mathrm{mg} / 100 \mathrm{~g})$, and the chloroform extract of the flower $(2.9 \mathrm{mg} / 100 \mathrm{~g})$.

The results revealed that there was a significant difference $(p<0.05)$ in the TFC obtained with the different solvents. The water extract exhibited the highest significant TFC for all the different parts of the kenaf plant. The water extract of the flower had the highest TFC $(755.2 \mathrm{mg} / 100 \mathrm{~g})$; this was followed by the methanol extract of the flower $(620.0 \mathrm{mg} / 100 \mathrm{~g})$; the water extracts of the leaf $(563.7$ $\mathrm{mg} / 100 \mathrm{~g})$, the seed $(331.1 \mathrm{mg} / 100 \mathrm{~g})$, and the stem bark $(299.3 \mathrm{mg} / 100 \mathrm{~g})$; the chloroform extract of the seed $(154.2 \mathrm{mg} / 100 \mathrm{~g})$; the methanol extract of the leaf $(126.7$ $\mathrm{mg} / 100 \mathrm{~g})$; the ethanol extracts of the flower (126.4 $\mathrm{mg} / 100 \mathrm{~g})$ and the seed $(98.9 \mathrm{mg} / 100 \mathrm{~g})$; the methanol extract of the stem bark $(70.2 \mathrm{mg} / 100 \mathrm{~g})$; the ethanol extracts of the leaf $(40.2 \mathrm{mg} / 100 \mathrm{~g})$ and the stem bark $(38.0 \mathrm{mg} / 100 \mathrm{~g})$; the methanol extract of the seed $(17.5$ $\mathrm{mg} / 100 \mathrm{~g})$; and the chloroform extracts of the flower, the stem bark $(8.7 \mathrm{mg} / 100 \mathrm{~g})$, and the leaf $(4.8 \mathrm{mg} / 100 \mathrm{~g})$.

\section{UPLC analysis}

The representative UPLC fingerprint chromatograms of the different parts of the kenaf plant are shown in Table 2 and Fig. S2. The measurement of phenolic compounds was not possible for the chloroform extracts of the leaf, stem bark and flower. Six compounds were detected for the water extract of the leaf: kaempferitrin $(178.2 \mathrm{mg} / 100 \mathrm{~g})$, kaempferol glycoside $(59.2 \mathrm{mg} / 100 \mathrm{~g})$, caffeic acid $(76.4 \mathrm{mg} / 100$ g), afzelin (38.5 mg/100 g), chlorogenic acid (23.4 mg/100 $\mathrm{g})$, and isoquercitrin $(18.0 \mathrm{mg} / 100 \mathrm{~g})$. Six compounds were detected for the methanol extract of the leaf: kaempferitrin $(29.6 \mathrm{mg} / 100 \mathrm{~g})$, caffeic acid $(7.9 \mathrm{mg} / 100 \mathrm{~g})$, kaempferol glycoside $(7.0 \mathrm{mg} / 100 \mathrm{~g})$, afzelin $(5.9 \mathrm{mg} / 100 \mathrm{~g})$, chlorogenic acid $(2.6 \mathrm{mg} / 100 \mathrm{~g})$, and isoquercitrin $(2.5 \mathrm{mg} / 100 \mathrm{~g})$. Six compounds were detected for the chloroform extract of the leaf: chlorogenic acid (0.5 mg/100 g), kaemperitrin (0.1 $\mathrm{mg} / 100 \mathrm{~g})$. Nine compounds were detected for the ethanol extract of the leaf: kaemperitrin $(10.0 \mathrm{mg} / 100 \mathrm{~g})$, an unknown compound $(8.0 \mathrm{mg} / 100 \mathrm{~g})$, naringin $(7.6 \mathrm{mg} / 100 \mathrm{~g})$, naringin isomer $(5.1 \mathrm{mg} / 100 \mathrm{~g})$, kaempferol glycoside $(2.2 \mathrm{mg} / 100$ 
Table 2 Phytochemical constituents in different kenaf tissues in various solvents by UPLC

$(\mathrm{mg} / 100 \mathrm{~g})$

\begin{tabular}{|c|c|c|c|c|c|}
\hline No. & Name of the compound & Methanol & Water & Ethanol & Chloroform \\
\hline \multicolumn{6}{|c|}{ Leaf } \\
\hline 1 & Chlorogenic acid & $2.6 \mathrm{~b}$ & $23.4 \mathrm{a}$ & $0.4 \mathrm{c}$ & $0.5 \mathrm{c}$ \\
\hline 2 & Caffeic acid & $7.9 \mathrm{~b}$ & $76.4 \mathrm{a}$ & $1.3 \mathrm{c}$ & $-d$ \\
\hline 3 & Kaempferol glycoside & $7.0 \mathrm{~b}$ & $59.2 \mathrm{a}$ & $2.2 \mathrm{c}$ & $-d$ \\
\hline 4 & Afzelin & $5.9 \mathrm{~b}$ & $38.5 \mathrm{a}$ & $1.9 \mathrm{~b}$ & $-d$ \\
\hline 5 & Isoquercitrin & $2.5 b$ & $18.0 \mathrm{a}$ & $0.8 \mathrm{c}$ & $-d$ \\
\hline 6 & Kaempferitrin & $29.6 b$ & $178.2 \mathrm{a}$ & $10.0 \mathrm{c}$ & $0.1 \mathrm{~d}$ \\
\hline 7 & Unknown & $-b$ & $-b$ & $8.0 \mathrm{a}$ & $-b$ \\
\hline 8 & Naringin & $-b$ & $-b$ & $7.6 \mathrm{a}$ & $-b$ \\
\hline 9 & Naringin isomer & $-b$ & $-b$ & $5.1 \mathrm{a}$ & $-b$ \\
\hline \multicolumn{6}{|c|}{ Bark } \\
\hline 1 & Gallic acid & $1.5 b$ & $4.7 \mathrm{a}$ & $-\mathrm{c}$ & $-\mathrm{c}$ \\
\hline 2 & $p$-Hydroxybenzoic acid & $1.0 \mathrm{~b}$ & $15.9 \mathrm{a}$ & $-\mathrm{c}$ & $-\mathrm{c}$ \\
\hline 3 & Vanillin & $2.1 b$ & $19.9 \mathrm{a}$ & $-\mathrm{c}$ & $-\mathrm{c}$ \\
\hline 4 & Caffeic acid isomer & $1.5 \mathrm{a}$ & $18.9 \mathrm{a}$ & $-\mathrm{c}$ & $-c$ \\
\hline 5 & Caffeic acid & $5.2 \mathrm{a}$ & $51.3 \mathrm{a}$ & $-\mathrm{c}$ & $-\mathrm{c}$ \\
\hline 6 & Kaempferol glycoside & $2.9 \mathrm{~b}$ & $10.0 \mathrm{a}$ & $4.2 b$ & $-\mathrm{c}$ \\
\hline 7 & Afzelin & $4.9 \mathrm{~b}$ & $13.7 \mathrm{a}$ & $4.5 b$ & $-\mathrm{c}$ \\
\hline 8 & Isoquercitrin & $2.8 b$ & $9.5 \mathrm{a}$ & $1.1 \mathrm{~b}$ & $-c$ \\
\hline 9 & Kaempferitrin & $17.5 \mathrm{~b}$ & $25.0 \mathrm{a}$ & $24.1 \mathrm{c}$ & $-d$ \\
\hline \multicolumn{6}{|c|}{ Flower } \\
\hline 1 & $p$-Hydroxybenzoic acid & $9.1 \mathrm{~b}$ & $36.0 \mathrm{a}$ & $-\mathrm{c}$ & $-c$ \\
\hline 2 & Anthocyanin $(520 \mathrm{~nm})$ & $14.8 \mathrm{~b}$ & $41.4 \mathrm{a}$ & $1.5 \mathrm{c}$ & - \\
\hline 3 & Caffeic acid & $5.2 \mathrm{~b}$ & $17.7 \mathrm{a}$ & $3.5 b$ & $-\mathrm{c}$ \\
\hline 4 & Unknown compound & $3.8 \mathrm{~b}$ & $11.8 \mathrm{a}$ & $2.5 b$ & $-\mathrm{c}$ \\
\hline 5 & Myricetin glycoside & $162.5 \mathrm{a}$ & $142.5 b$ & $44.7 \mathrm{c}$ & $-d$ \\
\hline \multicolumn{6}{|c|}{ Seed } \\
\hline 1 & Gallic acid & $1.1 b$ & $6.7 \mathrm{a}$ & $1.3 b$ & $-\mathrm{c}$ \\
\hline 2 & $p$-Hydroxybenzoic acid & $3.0 \mathrm{~b}$ & $95.5 \mathrm{a}$ & $-c$ & $-\mathrm{c}$ \\
\hline 3 & syringic acid & $0.8 b$ & $13.5 \mathrm{a}$ & $-\mathrm{c}$ & $-\mathrm{c}$ \\
\hline 4 & p-coumaric acid & $-b$ & $26.7 \mathrm{a}$ & $-b$ & $-b$ \\
\hline 5 & Vanillin & $0.6 b$ & $44.3 \mathrm{a}$ & $-c$ & $-c$ \\
\hline 6 & Tannic acid & $1.3 \mathrm{c}$ & $-d$ & $9.7 \mathrm{~b}$ & $14.0 \mathrm{a}$ \\
\hline 7 & Tannic acid isomer & $1.5 \mathrm{c}$ & $-d$ & $7.7 b$ & $11.1 \mathrm{a}$ \\
\hline 8 & Proanthocyanidin & $-c$ & $-c$ & $8.0 \mathrm{~b}$ & $13.2 \mathrm{a}$ \\
\hline 9 & Proanthocyanidin isomer & $-\mathrm{c}$ & $-\mathrm{c}$ & $8.7 b$ & $12.4 \mathrm{a}$ \\
\hline 10 & Unknown & $-b$ & $-b$ & $5.1 \mathrm{a}$ & $5.8 \mathrm{a}$ \\
\hline 11 & Naringin & $-b$ & $-b$ & $4.3 \mathrm{a}$ & $6.5 \mathrm{a}$ \\
\hline 12 & Naringin isomer & $-b$ & $-b$ & $4.1 \mathrm{a}$ & $6.7 \mathrm{a}$ \\
\hline
\end{tabular}

${ }^{\mathrm{a}, \mathrm{b}, \mathrm{c}, \mathrm{d}}$ Different letters indicate a significant difference at the $5 \%$ level (Duncan's multiple range tests, $\mathrm{n}=3$ ).

g), afzelin (1.9 mg/100 g), caffeic acid (1.3 mg/100 g), isoquercitrin $(0.8 \mathrm{mg} / 100 \mathrm{~g})$, and chlorogenic acid $(0.4$ $\mathrm{mg} / 100 \mathrm{~g})$.

Nine compounds were detected in the water and methanol extracts of the stem bark: caffeic acid (water: $51.3 \mathrm{mg} / 100$ g; methanol: $5.2 \mathrm{mg} / 100 \mathrm{~g}$ ), kaempferitrin (water: $25.0 \mathrm{mg} / 100$ g; methanol: $17.5 \mathrm{mg} / 100 \mathrm{~g}$ ), vanillic acid (water: $19.9 \mathrm{mg} / 100$ g; methanol: $2.1 \mathrm{mg} / 100 \mathrm{~g}$ ), caffeic acid isomer (water: 18.9 $\mathrm{mg} / 100 \mathrm{~g}$; methanol: $1.5 \mathrm{mg} / 100 \mathrm{~g}$ ), p-hydroxybenzoic acid (water: $15.9 \mathrm{mg} / 100 \mathrm{~g}$; methanol: $1.0 \mathrm{mg} / 100 \mathrm{~g}$ ), afzelin (water: $13.7 \mathrm{mg} / 100 \mathrm{~g}$; methanol: $4.9 \mathrm{mg} / 100 \mathrm{~g}$ ), kaempferol glycoside (water: $10.0 \mathrm{mg} / 100 \mathrm{~g}$; methanol: 2.9 $\mathrm{mg} / 100 \mathrm{~g}$ ), isoquercitrin (water: $9.5 \mathrm{mg} / 100 \mathrm{~g}$; methanol: $2.8 \mathrm{mg} / 100 \mathrm{~g}$ ), and gallic acid (water: $4.7 \mathrm{mg} / 100 \mathrm{~g}$; methanol: $1.5 \mathrm{mg} / 100 \mathrm{~g}$ ). Four compounds were detected in the ethanol extract of the stem bark: kaempferitrin (24.1 $\mathrm{mg} / 100 \mathrm{~g}$ ), afzelin (4.5 mg/100 g), kaempferol glycoside $(4.2 \mathrm{mg} / 100 \mathrm{~g})$, and isoquercitrin $(1.1 \mathrm{mg} / 100 \mathrm{~g})$.

Five compounds were detected in the water and methanol extracts of the flower: myricetin glycoside (water: 142.5 $\mathrm{mg} / 100 \mathrm{~g}$; methanol: $162.5 \mathrm{mg} / 100 \mathrm{~g}$ ), anthocyanin (water: $41.4 \mathrm{mg} / 100 \mathrm{~g}$; methanol: $14.8 \mathrm{mg} / 100 \mathrm{~g}$ ), p-hydroxybenzoic 
acid (water: $36.0 \mathrm{mg} / 100 \mathrm{~g}$; methanol: $9.1 \mathrm{mg} / 100 \mathrm{~g}$ ), caffeic acid (water: $17.7 \mathrm{mg} / 100 \mathrm{~g}$; methanol: $5.2 \mathrm{mg} / 100 \mathrm{~g}$ ), and an unknown compound (water: $11.8 \mathrm{mg} / 100 \mathrm{~g}$; methanol: $3.8 \mathrm{mg} / 100 \mathrm{~g}$ )., Four compounds were detected in the ethanol of the flower: myricetin glycoside $(44.7 \mathrm{mg} / 100 \mathrm{~g})$, anthocyanin $(1.5 \mathrm{mg} / 100 \mathrm{~g})$, caffeic acid $(3.5 \mathrm{mg} / 100 \mathrm{~g})$, and an unknown compound $(2.5 \mathrm{mg} / 100 \mathrm{~g})$

Five compounds were detected in the water extract of the seed: $p$-hydroxybenzoic acid $(95.5 \mathrm{mg} / 100 \mathrm{~g})$, vanillin (44.3 mg/100 g), $p$-coumaric acid $(26.7 \mathrm{mg} / 100 \mathrm{~g})$, syringic acid $(13.5 \mathrm{mg} / 100 \mathrm{~g})$, and gallic acid $(6.7 \mathrm{mg} / 100 \mathrm{~g})$. Six compounds were detected in the methanol extract of the seed: $p$-hydroxybenzoic acid $(3.0 \mathrm{mg} / 100 \mathrm{~g})$, tannic acid $(1.3 \mathrm{mg} / 100 \mathrm{~g})$, tannic acid isomer $(1.5 \mathrm{mg} / 100 \mathrm{~g})$, gallic acid $(1.1 \mathrm{mg} / 100 \mathrm{~g})$, and syringic acid $(0.8 \mathrm{mg} / 100 \mathrm{~g})$. Eight compounds were detected in the ethanol extract of the seed: tannic acid $(9.7 \mathrm{mg} / 100 \mathrm{~g})$, tannic acid isomer (7.7 mg/100 g), proanthocyanidin (8.0 mg/100 g), proanthocyanidin isomer $(8.7 \mathrm{mg} / 100 \mathrm{~g})$, an unknown compound $(5.1 \mathrm{mg} / 100 \mathrm{~g})$, naringin $(4.3 \mathrm{mg} / 100 \mathrm{~g})$, naringin isomer $(4.1 \mathrm{mg} / 100 \mathrm{~g})$, and gallic acid $(1.3 \mathrm{mg} / 100 \mathrm{~g})$. Seven compounds were detected in the chloroform extract of the seed: tannic acid $(14.0 \mathrm{mg} / 100 \mathrm{~g})$, tannic acid isomer $(11.1 \mathrm{mg} / 100$ $\mathrm{g})$, proanthocyanidin $(13.2 \mathrm{mg} / 100 \mathrm{~g})$, proanthocyanidin isomer (12.4 mg/100g), an unknown compound $(5.8 \mathrm{mg} / 100 \mathrm{~g})$, naringin $(6.5 \mathrm{mg} / 100 \mathrm{~g})$, and naringin isomer $(6.7 \mathrm{mg} / 100 \mathrm{~g})$.

\section{Antioxidant activity}

The results of the DPPH radical scavenging activity of the different solvent extracts of the parts of the kenaf plant are shown in Fig. 3-A. The water extracts of the flower, leaf, and seed $(80.6 \%, 73.2 \%$, and $70.4 \%$, respectively), and the methanol extract of the flower $(71.84 \%)$ exhibited the greatest DPPH radical scavenging activity, this was followed by the methanol extract of the leaf $(62.1 \%)$, the ethanol extract of the leaf (37.7), the water extract of the stem bark $(29.1 \%)$, the ethanol extracts of the seed and stem bark ( $21.1 \%$ and $15.4 \%$, respectively), the methanol extracts of the stem bark and seed (15.2\% and 5.1\%, respectively), the chloroform extracts of the leaf, flower, and stem bark $(4.0 \%, 2.0 \%$, and $1.0 \%$, respectively). The results of the SOD activity of the different solvent extracts of the parts of the kenaf plant are shown in Fig. 3-B. The water extract of the leaf, seed and flower and methanol extract of the leaf and flower give the maximum SOD activity among the other extracts.
A

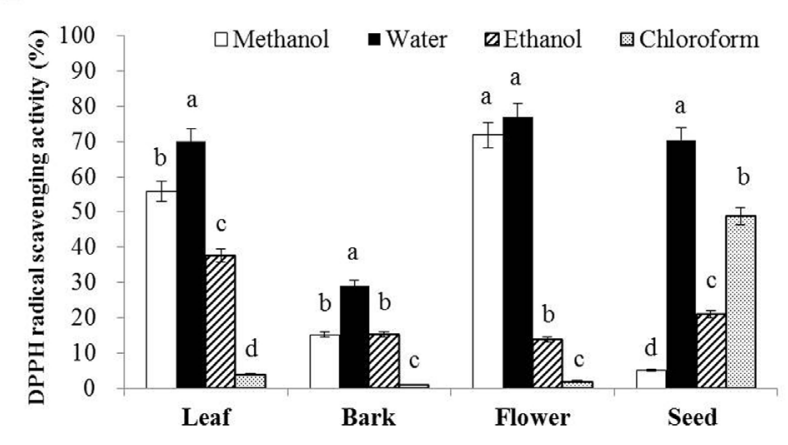

B

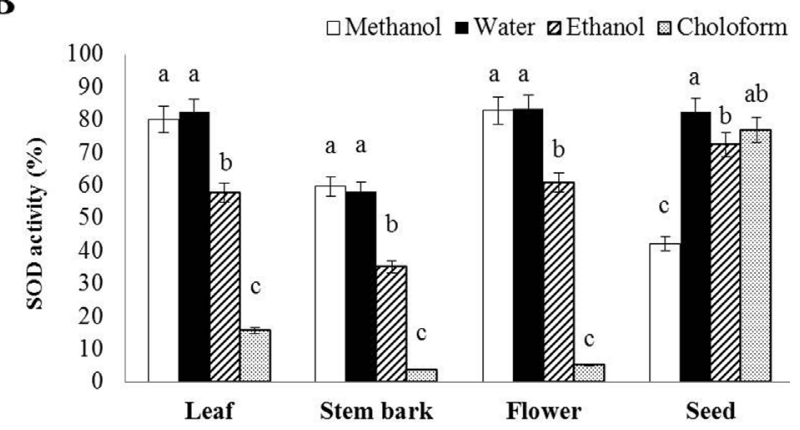

Fig. 3 2,2-diphenyl-1-picrylhydrazyl (DPPH) radical scavenging activity (A) and superoxide dismutase (SOD) activity (B) for the different kenaf tissues. Superscript letters indicate significant differences at the $5 \%$ level (Duncan's multiple range tests, $n=3$ )

\section{Discussion}

The results of this study revealed the presence of phytocompounds in the hexane extracts of the different parts of the kenaf plant by GC-MS analysis. The leaf extract contained 13 phytocomponds, of which E-phytol and 9,12,15-octadecatrienoic acid were the most predominant. Phytol and linolenic acid have medicinal properties. Phytol is an oxygenated diterpene that is a precursor for vitamins $\mathrm{E}$ and $K_{1}$ and is used with simple sugar in candies (Ebije et al. 2014). Phytol exhibits antibacterial activity against Staphylococcous aureus, Colletotrichum fragariae, Colletotrichum gloeosporioides, and Colletotrichum accutatum by causing damage to cell membranes, which results in a leakage of potassium ions from bacterial cells (Kobaisy et al. 2001; Inoue et al. 2005; Nandagopalan et al. 2015). Extracts of the stem bark identified eight phytocompounds, primarily fatty acids, of which hexadecanoic acid and 9,12,15octadecatrienoic acid were the most abundant. Rauter et al. (2002) reported that the major compounds identified in the petroleum extract of the stem bark of kenaf were fatty acids (hexadecanoic acid and 9,12-octadecadienoic acid). 
The main components of the flower extract were identified as hydrocarbons (52.8\%) and fatty acids (47.2\%). Similarly, Ebije et al. (2014) reported that the major compound identified in the Hibiscus sabdariffa flower was hexadecanoic acid. Hydrocarbon compounds have been shown to exhibit antimicrobial activity (Kobaisy et al. 2001; Ebije et al. 2014). Kenaf seeds oil is used for margarine, and it is thus safe for human and animals (Mohamed et al. 1995; Ghafar et al. 2012; Alexopoulou et al. 2013; Ghafar et al. 2013; Ryu et al. 2016).

The phenolic and flavonoid compounds present in the plant body suggest its medicinal importance (Kobaisy et al. 2001; Nyam et al. 2009; Chen et al. 2014). The functional groups in phenolic and flavonoid compounds present in the kenaf plant exhibit antioxidant properties and inhibit the angiotensin I-converting enzyme and lipid peroxidation (Jin et al. 2013; Ghafar et al. 2013). In this study, the TPC and TFC of the kenaf leaf and flower were promising. Among the solvents studied, the highest content of phenylpropanoid and phenolic compounds were observed in the water extract. The major compounds identified in the different parts of the kenaf plant were kaemperitrin in the leaf, caffeic acid in the stem bark, myricetin glycoside in the flower, and $p$-hydroxybenzoic acid in the seed for water extract. In the present study, extraction using a binary water solvent was adopted after considering health and safety (Sultana et al. 2007; Yusri et al. 2012). Our experimental results are consistent with previous reports, suggesting that a binary solvent system is superior to a solvent system in which phenolic compounds are extracted according to their relative polarity (Wang et al. 2008). Water is the best solvent for the extraction of functional compounds from the kenaf plant, with the exceptions of myricetin glycoside, tannic acid, proanthocyanidin, and naringin. Furthermore, we saw high levels of antioxidant activity, which may have been due to the increase in kaempferitrin, anthocyanin, $p$-hydroxybenzoic acid, or other minor compounds. Similarly, water has been suggested to be the most effective solvent for the extraction of functional compounds from the fresh leaves, stem barks, and seeds of Calotropis procera (Abegunde and Ayodele-Oduola, 2013). Kaempferitrin was found to have an acute lowering effect on blood glucose levels in diabetic rats and showed decreased lipid peroxidation and antimicrobial and anti-inflammatory effects in macrophage cells (Jorge et al. 2004; Jin et al. 2013; Zhao et al. 2014). Caffeic acid is a well-known polyphenolic compound with strong antioxidant activity (Chen et al. 2014). de Freitas et al. (2013) reported that the water extract from the stem bark of Scutia buxifolia revealed a high concentration of caffeic acid. The compounds identified in the flowers of the genus Hibiscus include anthocyanins, flavonoids, and polyphenols (Khare, 2007; Salem et al. 2014; Obouayeba et al. 2015). Rakhimkhanov et al. (1970) reported that the kenaf flower contained the anthocyanin, delphinidin 3-0-flD-glycosyl-fl-D-xyloside, which we have called cannabinidin. The kenaf flowers are a potential source of antioxidants, including anthocyanins and phenolic compounds (Rakhimkhanov et al. 1970; Khare, 2007; Salem et al. 2014). The kenaf flowers have been relegated to the status of little-known functional food sources. However, their potential as a new source of edible flowers and natural food colorants may elevate their status. The phytoconstituents present in the different parts of the kenaf plant may explain their medicinal characteristics. In the future, the isolation and purification of these phytocompounds may be useful in the preparation of novel drugs for the treatment of disease.

The potential of the kenaf plant as an important source of functional compounds in the tropics is highlighted in the present study. Our results showed that the extraction solvents significantly altered the TPC, TAC and antioxidant activity of the different parts of the plant, and water was the optimal solvent for the extraction of functional compounds and antioxidant activity. These results agree with Jin et al. (2013) who reported that TPC, TAC plays an important role in the antioxidant activities in kenaf. The results of phytochemical analysis and antioxidant in different part of kenaf are suitable for source of functional food and drugs.

\section{Acknowledgement}

This work was supported by a grant from the Korea Atomic Energy Research Institute (KAERI), Republic of Korea.

\section{Refemces}

Abegunde SM, Ayodele-Oduola RO (2013) Comparison of efficiency of different solvents used for the extraction of phytochemicals from the leaf, seed and stem bark of Calotropis procera. IJSR.4: 835-838

Alexopoulou E, Papattheohari Y, Christou M, Monti A (2013) Keanf: A multi-purpose crop for sever industrial applications. Springer-verlag, London. pp.1-15

Chen KW, Iqbal S, Khong NMH, Ooi DJ, Ismail M (2014) Antioxidant activity of phenolicsesaponins rich fraction prepared from defatted kenaf seed meal. LWT-Food Sci. Techno. 56:181-186

De Freitas RB, Rovani BT, Boligon AA, de Brum TF, Piana M, da 
Silva Jesus R, Veloso CF, Kober H, Moresco RN, da Costa Araldi IC, de Freitas Bauermann ICL, Athayde ML (2013) Hepatotoxicity evaluation of aqueous extract from Scutia buxifolia. Molecules18:7570-7583

Ebije I, Oladipupo A, Lawal AOO, Isiaka AO (2014) Volatile composition of the floral essential oil of Hibiscus sabdariffa L.from Nigeria. AJEONP. 2:04-07

Ghafar SAA, Ismail M, Yazan LS, Fakurazi S, Ismail N, Chan KW, Tahir PM (2013) Cytotoxic activity of kenaf seed oils from supercritical carbon dioxide fluid extraction towards human colorectal cancer (HT29) cell lines. Evid. Based Complement. Alternat. Med. 2013:549705

Ghafar SAA, Yazan LS, Tahir PM, Ismail M (2012) Kenaf seed supercritical fluid extract reduces aberrant crypt foci formation in azoxymethane-induced rats. Exp.Toxic. Pathol.16:247-251

Hossain MD, Hanafi MM, Jol H, Jamal T (2011) Dry matter and nutrient partitioning of kenaf(Hibiscus cannabinus L.) varieties grown on sandy bris soil. Aust. J. Crop Sci. 5(6):654-659

Inoue Y, Hada T, Shiraishi A, Hirore K, Hamashima H, Kobayashi S (2005) Biphasic effects of geranylgeraniol, teprenone, and phytol on the growth of Staphylococcus aureus. Antimicrob.agents Chemother.49:1770-1774

Jin CW, Ghimeray AK, Wang L, Xu ML, Piao JP, Cho DH(2013) Far infrared assisted kenaf leaf tea preparation and its effect on phenolic compounds, antioxidant and ACE inhibitory activity. 2013. J.Med.Plants Res. 7:1121-1128

Jorge AP, Horst H, Sousa E, Pizzolatti MG, Silva FRMB (2004) Insulinomimetic effects of kaempferitrin on glycaemia and on ${ }^{14} \mathrm{C}$ glucose uptake in rat soleus muscle. Chem.Biol.Inter.149: 89-96

Khare CP (2007) Indian medicinal plants; An illustrated dictionary. Springer-verlag, London. p. 309

Kobaisy M, Tellez MR, Webber CL, Dayan FE, Schrader KK, Wedge DE (2001) Phytotoxic and fungitoxic activities of the essential oil of kenaf (Hibiscus cannabinus L.) leaves and its composition. J.Agric.Food Chem.49:3768-3771

Kubmarawa D, Andenyang IFH, Magomya AM (2009) Proximate composition and amino acid profile of two non-conventional leafy vegetables (Hibiscus cannabinus and Haematostaphis barteri). Afr.J.Food Sci. 3:233-236

Mohamed A, Bhardwaj H, Hamama A, Webber C (1995) Chemical composition of kenaf (Hibiscus cannabinus L.)seed oil. Ind. Crop Prod. 4:157-165

Nandagopalan V, Johnson Gritto M, Doss A (2015) GC-MS analysis of bioactive components of the methanol extract of Hibiscus tiliaceus Linn. Asian J. Plant Sci. Res. 5:6-10

Nyam KL, Tan CP, Lai OM, Long K, Che Man YB (2009) Physicochemical properties and bioactive compounds of selected seed oils. Food Sci.Techol. 42:1396-1403

Obouayeba AP, Diarrassouba M, Soumahin EF, Kouakou TH(2015) Phytochemical analysis, purification and identification of Hibiscus anthocyanins. J.Pharm.Chem.Biol.Sci. 3:156-168

Rakhimkhanov ZB, Sadykov AS, Ismailov AI, Karimdzhanov AK (1970) A study of the anthocyanins of kenaf. Khimiya Prirodnykh Soedinenii. 6:129-130

Rauter A, Palma FB, Justino J, Araujo ME, Santos SP (2002) Natural Products in the New Millennium: Prospects and Industrial Application. Kluwer academic publishers, Dordreche, Netherlands. pp. 47-57

Ryu J, Ha BK, Kim DS, Kim JB, Kim SH, Kang SY (2013) Assessment of growth and seed oil composition of kenaf (Hibiscus cannabinus L.) germplasm. J.Crop Sci. Biotech. 16: 297-302

Ryu, J, Kwon SJ, Ahn JW, Ha BK, Jeong SW, Im SB, Kim JB, Kim SH, Lee YK, Kang SY (2016) Evaluation of nutritive value and identification of fungi in silage from new kenaf (Hibiscus cannabinus) cultivars. Int.J.Agric.Biol.18:1159-1168

Salem MZM, Olivares-Perez J, Salem AZM (2014) Studies on biological activities and phytochemicals composition of Hibiscus species-A review. Life Sci. J. 11:1-8

Shaheen MA, El-Nakhlawy FS, Al-Shareef AR (2012). Roselle (Hibiscus sabdariffa L.) seeds as unconventional nutritional source. Afr.J.Biotech.11:9821-9824

Sultana B, Anwar F, Przybylski R (2007) Antioxidant activity of phenolic components present in barks of Azadirachta indica, Terminalia arjuna, Acacia nilotica, and Eugenia jambolana Lam.Trees. Food Chem. 104:1106-1114

Wang J, Sun B, Cao Y, Tian Y, Li X (2008) Optimisation of ultrasound-assisted extraction of phenolic compounds from wheat bran. Food Chem. 106:804-810

Yusri NM, Chen KW, Iqbal S, Ismail M(2012) Phenolic content and antioxidant activity of Hibiscus cannabinus L. seed extracts after sequential solvent extraction. Molecules17:12612-12621

Zhao S, Li X, Cho DH, Arasu MV, Al-Dhabi NA, Park SU (2014) Accumlation of kaempferitrin and expression of phenyl-propanoid biosynthetic genes in kenaf (Hibiscus cannabinus). Molecules 19:16987-16997

Zhishen J, Mengcheng T, Jianming W (1999) The determination of flavonoid contents in mulberry and their scavenging effects on superoxide radicals. Food Chem. 64:555-559 